\title{
Screening of Brazilian Basidiomycetes for Antimicrobial Activity
}

\author{
Luiz Henrique Rosa*, Kátia M Gomes Machado**, Camila Cristina Jacob, \\ Marina Capelari***, Carlos Augusto Rosa*, Carlos Leomar Zani/ ${ }^{+}$
}

Laboratório de Química de Produtos Naturais, Centro de Pesquisas René Rachou-Fiocruz, Av. Augusto de Lima 1715,30190002 Belo Horizonte, MG, Brasil *Departamento de Microbiologia, Instituto de Ciências Biológicas, Universidade Federal de Minas Gerais, Belo Horizonte, MG, Brasil **Fundação Centro Tecnológico de Minas Gerais, and Universidade Católica de Santos, Santos, SP, Brasil ***Seção de Micologia e Liquenologia, Instituto de Botânica, São Paulo, SP, Brasil

A total of 103 isolates of basidiomycetes, representing 84 species from different Brazilian ecosystems, were evaluated for their antifungal and antibacterial activity in a panel of pathogenic and non-pathogenic microorganisms. Tissue plugs of the fruiting bodies were cultivated in liquid media and the whole culture extracted with ethyl acetate. Crude extracts from Agaricus $c f$. nigrecentulus, Agrocybe perfecta, Climacodon pulcherrimus, Gloeoporus thelephoroides, Hexagonia hydnoides, Irpex lacteus, Leucoagaricus $c f$. cinereus, Marasmius $c f$. bellus, Marasmius $s p$., Nothopanus hygrophanus, Oudemansiella canarii, Pycnoporus sanguineus, Phellinus sp., and Tyromyces duracinus presented significant activity against one or more of the target microorganisms. Eight isolates were active only against bacteria while three inhibited exclusively the growth of fungi. Two extracts presented wide antimicrobial spectrum and were active against both fungi and bacteria. Differences in the bioactivity of extracts obtained from isolates from the same species were observed.

Key words: antibiotics - bacteria - basidiomycetes - fungi - yeasts

Many antibiotics in clinical use were developed from fungal and actinomycetes metabolites. During the last decades several pathogenic microorganisms developed resistance to the available antibiotics. Infections by multidrug resistant isolates of Candida spp., Staphylococcus epidermidis, S. aureus, Streptococcus spp., Enterococcus sp. and Escherichia coli, among others, became more and more frequent stimulating the search for new antibiotics with novel mechanisms of action (Kotra \& Mobashery 1998, Morschhäuser et al. 2000, Sandven 2000, Thomson \& Moland 2000).

The first investigations on the potential of basidiomycetes as sources of antibiotics were performed by Anchel, Hervey, Wilkins in 1941 (Sandven 2000), when they examined extracts of fruiting bodies and mycelia culture from over 2000 species. They succeed in the isolation and identification of pleuromutilin (Kavanagh et al. 1950), a diterpene that is especially useful for the treatment of mycoplasm infections in animals (Brizuela et al. 1998) and served for the development of the first commercial antibiotic of basidiomycete origin.

Moreover, interest in the metabolites produced by basidiomycetes declined as streptomycetes were considered to be a more prolific and easier to manipulate source of antibiotics (Anke 1989). However, over 6000 metabolites were already identified from these imperfect fungi, making it more and more difficult to isolate novel bioactive metabolites from them. With the development

Financial support: Fiocruz, Capes, CNPq, Fapemig (Process 0250252399)

${ }^{+}$Corresponding author. Fax: +55-31-3295.3566. E-mail: zani@cpqrr.fiocruz.br

Received 16 May 2003

Accepted 4 August 2003 of new fermentation and purification technologies, basidiomycetes are again receiving attention as potential sources of new classes of antibiotics (Anke 1989, Maziero et al. 1999, Suay et al. 2000).

In fact, several compounds that inhibit the growth of a large spectrum of saprophytic and phytopathogenic fungi were isolated from basidiomycetes (Anke 1989, 1995, 1997). Furthermore, these organisms are able to inhibit the development of bacteria, actinomycetes and other fungi from their microhabitat, indicating that the antimicrobial substances produced by them have important ecological implications (Sidorova \& Velikanov 2000). Despite their potential and enormous diversity in tropical ecosystems (Hawksworth 1991), few studies aiming at the discovery of bioactive compounds from basidiomycetes were conducted in Brazil. Most of the investigations were directed to edible mushrooms (Ishikawa et al. 2001, Paccola et al. 2001, Oliveira et al. 2002) or common, easily recognized species (Smânia et al. 1995a,b, 1997, 1999).

This work is part of a screening program aiming at the discovery of new bioactive metabolites from Brazilian basidiomycetes. We report herein the results of the collection, identification and screening of 84 species (103 isolates) of basidiomycetes in a bioassay panel employing five yeast and 12 bacteria of clinical importance.

\section{MATERIALS AND METHODS}

Fungi-One hundred and three basidiomycetes isolates from 84 species were collected at different locations in Brazil (Table I). The extracts were prepared from the basidiomes and from culture in liquid media. The basidiomes were collected in the Parque Estadual do Rio Doce (MG), and in the Reserva do Museu de História Natural da Universidade Federal de Minas Gerais (UFMG). The culture isolates were obtained from Basidiomycetes 
TABLE I

Identification of species studied, origin and isolate registration number

\begin{tabular}{|c|c|c|}
\hline Species & Locality & Isolate \\
\hline Agaricus cf. nigrecentulus Heinem. & MG & UFMGCB31 \\
\hline A. porosporus Heinem. & MG & CCB299 \\
\hline A. cf. trinitatensis Baker \& Dale & MG & UFMGCB32 \\
\hline Agaricus sp. & SP & CCB280 \\
\hline Agrocybe perfecta (Rick) Sing. & SP & CCB161 \\
\hline Auricularia fuscosuccinea (Mont.) Farl. & $\mathrm{SP}$ & CCB43 \\
\hline A. fuscosuccinea & SP & CCB265 \\
\hline A. fuscosuccinea & SP & CCB44 \\
\hline Cymatoderma dendriticum (Pers.) Reid & SP & CCB306 \\
\hline Climacodon pulcherrimus (Berk. \& Curt.) Nikol. & $\mathrm{AL}$ & CCB191 \\
\hline Coprinus sp. & MG & UFMGCB33 \\
\hline Coprinus sp. & MG & UFMGCB34 \\
\hline Cyptotrama asprata (Berk.) Redhead \& Ginns & MG & UFMGCB52 \\
\hline Fomitopsis sp. & MG & $\mathrm{Bm}$ \\
\hline Fomitopsis sp. & MG & $\mathrm{Bm}$ \\
\hline Ganoderma sp. & MG & $\mathrm{Bm}$ \\
\hline Gloeoporus thelephoroides (Hook.) Cunn. & MG & $\mathrm{Bm}$ \\
\hline Gloeoporus sp. & MG & UFMGCB35 \\
\hline Gymnopilus cf. areolatus Murr. & MG & UFMGCB36 \\
\hline G. aureobrunneus (Berk. \& Curt.) Murr. & $\mathrm{SP}$ & CCB373 \\
\hline G. chrysopellus (Berk. \& Curt.) Murr. & SP & CCB381 \\
\hline Hexagonia hydnoides (Sw.: Fr.) K. Fid. & MG & $\mathrm{Bm}$ \\
\hline Hydnopolyporus fimbriatus (Fr.) Reid & $\mathrm{SP}$ & CCB289 \\
\hline Hydnopolyporus sp. & SP & CCB371 \\
\hline Inonotus $\mathrm{sp}$. & MG & $\mathrm{Bm}$ \\
\hline Irpex lacteus (Fr.: Fr.) Cooke & $\mathrm{SP}$ & CCB196 \\
\hline Lentinus bertieri (Fr.) Fr. & SP & $\mathrm{CCB} 255$ \\
\hline L. bertieri & MG & $\mathrm{Bm}$ \\
\hline L. critinus (L.: Fr.) Fr. & MS & CCB217 \\
\hline L.critinus & SP & CCB356 \\
\hline L. squarrosulus Mont. & SP & $\mathrm{CCB} 256$ \\
\hline L. striatulus Lév. & SP & $\mathrm{CCB} 253$ \\
\hline L. strigellus Berk. & $\mathrm{MG}$ & UFMGCB37 \\
\hline Lentinus cf. strigosus (Schwein.) Fr. & $\mathrm{SP}$ & CCB162 \\
\hline L. cf. strigosus & $\mathrm{SP}$ & CCB178 \\
\hline L. cf. strigosus & SP & $\mathrm{CCB} 250$ \\
\hline L. villosus Klotzsch & SP & CCB271 \\
\hline Lentinus sp. & $\mathrm{SP}$ & $\mathrm{CCB} 174$ \\
\hline Lentinus sp. & MG & UFMGCB38 \\
\hline Lentinus sp. & MG & $\mathrm{Bm}$ \\
\hline Lepiota sp. & MG & UFMGCB39 \\
\hline Leucoagaricus cf. cinereus (Quél.) Bom. \& Boiff. & MG & UFMGCB40 \\
\hline Leucocoprinus cf. longistriatus (Peck) Smith \& Weber & MG & $\mathrm{Bm}$ \\
\hline Leucocoprinus sp. & MG & UFMGCB41 \\
\hline Marasmius allocystis Sing. & MG & UFMGCB42 \\
\hline M. cf. bellus Berk. & MG & UFMGCB43 \\
\hline M. cladophyllus Berk. & SP & CCB360 \\
\hline Marasmius sp. & MG & UFMGCB44 \\
\hline Marasmius sp. & MG & UFMGCB45 \\
\hline Marasmius sp. & $\mathrm{SP}$ & $\mathrm{CCB} 378$ \\
\hline Merulius corium (Pers.) Fr. & SP & CCB355 \\
\hline Nothopanus hygrophanus (Mont.) Sing. & MS & CCB216 \\
\hline Oudemansiella canarii (Jungh.) Hohn & SP & $\mathrm{CCB} 241$ \\
\hline O. canarii & SP & CCB179 \\
\hline Peniophora cinerea (Fr.) Cook & SP & CCB204 \\
\hline P. utriculosa Cunn. & SP & CCB282 \\
\hline Phellinus fastuosus (Lév.) Ryv. & SP & $\mathrm{CCB} 205$ \\
\hline P. gilvus (Schw.) Pat. & $\mathrm{AL}$ & CCB190 \\
\hline P.gilvus & $\mathrm{SP}$ & $\mathrm{CCB} 317$ \\
\hline P.gilvus & $\mathrm{AL}$ & CCB186 \\
\hline P.gilvus & MG & $\mathrm{Bm}$ \\
\hline P. grenadensis (Murr.) Ryv. & SP & CCB484 \\
\hline
\end{tabular}




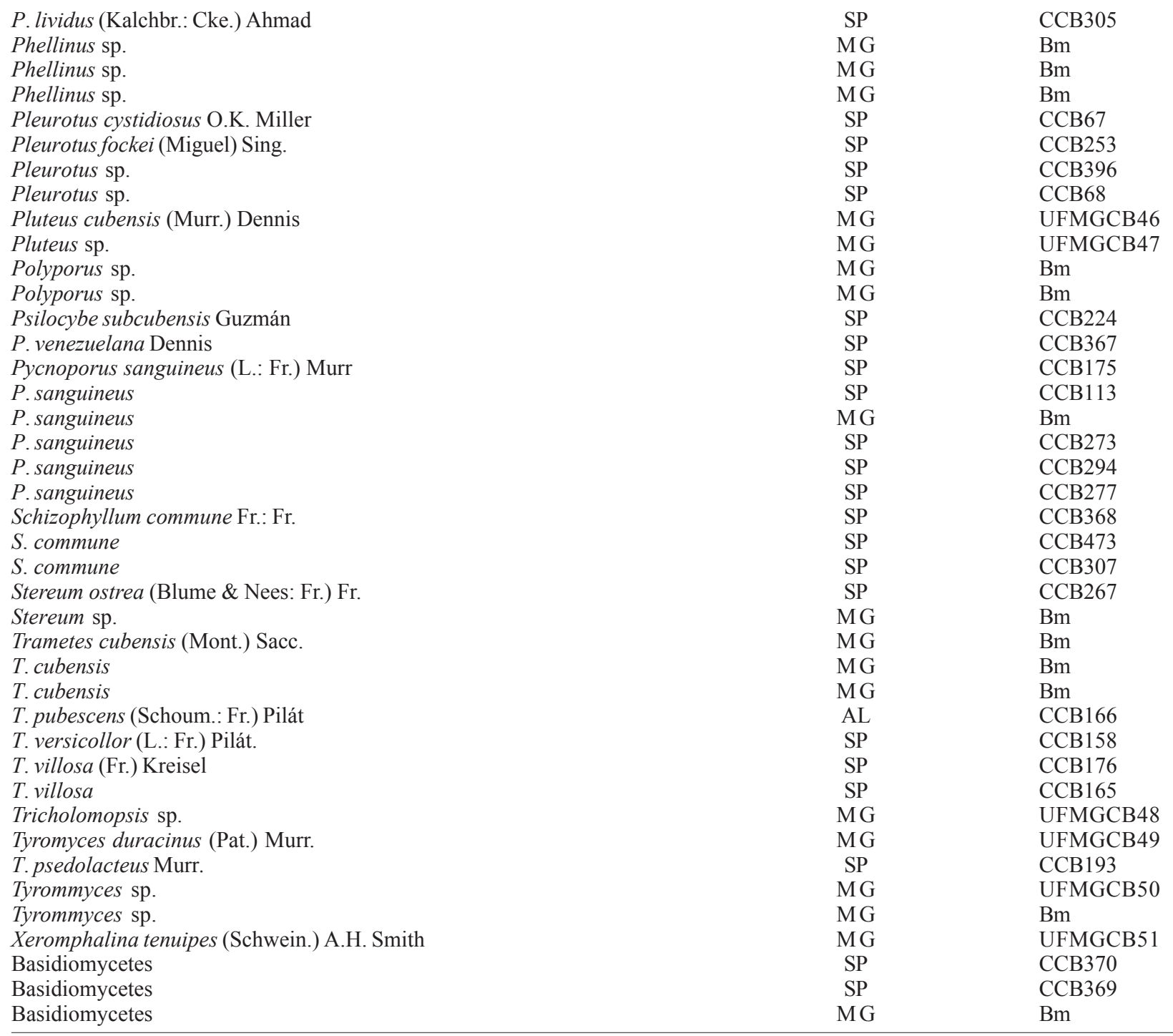

AL: Alagoas; MG: Minas Gerais; MS: Mato Grosso do Sul; SP: São Paulo; CCB: Basidiomycetes Culture Collection of the Instituto de Botânica, São Paulo, Brazil; UFMGCB: Basidiomycetes Culture Collection of the Universidade Federal de Minas Gerais, Belo Horizonte, MG, Brazil; Bm: Basidiome

Culture Collection (CCB) of the Instituto de Botânica (SP) and from the some basidiomes colleted at Parque Estadual do Rio Doce (MG), Estação Ecológica (MG) and Reserva do Museu de História Natural da UFMG.

Axenic cultures were obtained from the inner fragments of the living tissues of the fruitbodies using Potato Dextrose Agar (PDA, Difco, US) medium supplemented with chloramphenicol $(200 \mu \mathrm{g} / \mathrm{l})$ (Sigma, US). They were deposited in the culture collection CCB of the Instituto de Botânica and UFMGCB (Coleção de Culturas de Basidiomicetos da Universidade Federal de Minas Gerais). All isolates were maintained in Malt Extract Agar medium (MEA, Difco) and preserved as agar plugs in distilled water at $4^{\circ} \mathrm{C}$ (Castellani 1967). The collected specimens were identified according to methods of classical herbarium taxonomy. The main taxonomic works of Dennis (1970), Heinemann (1961,
1977, 1993), Pegler (1983, 1997), Gilbertson and Ryvarden (1986, 1987), Ryvarden $(1987,1991)$ were used to identify the species.

Growth conditions - Pre-inocula for the cultures were prepared by aseptically transferring three $5 \mathrm{~mm}$ discs from the culture on MEA slants into unbaffled $250 \mathrm{ml}$ Erlenmeyer flasks containing $25 \mathrm{ml}$ of MEC medium (malt extract $2 \%$, peptone $0.1 \%$, glucose $1.5 \%$ ). The flasks were shaken at $150 \mathrm{rpm}$ and $28^{\circ} \mathrm{C}$ for five days. The contents of the preinocula flasks were transferred to $250 \mathrm{ml}$ Erlenmeyer flasks containing $100 \mathrm{ml}$ of MEC. The inoculated flasks were shaken at $150 \mathrm{rpm}$ at $28^{\circ} \mathrm{C}$ for nine days. The flasks were frozen $\left(-20^{\circ} \mathrm{C}\right)$ until extraction.

Extraction - The cultures were thawed at ambient temperature and homogenised using a high-speed blender. The homogenate was extracted with ethyl acetate $(5 \times 30$ $\mathrm{ml}$ ) and the organic fraction dried over anhydrous sodium 
sulphate. The solvent was removed in a rotary-evaporator under vacuum at temperatures below $45^{\circ} \mathrm{C}$. After removing the residual solvent in a vacuum centrifuge at $40^{\circ} \mathrm{C}$, stock solutions $(10 \mathrm{mg} / \mathrm{ml})$ were prepared in dimethylsulfoxide (DMSO) and stored at $-40^{\circ} \mathrm{C}$. The basidiomes were triturated and extracted with ethanol for $24 \mathrm{~h}$ at room temperature in the dark. The solvent was eliminated as above.

Determination of antimicrobial activity - In vitro antimicrobial susceptibility tests were performed using a panel of pathogenic and non-pathogenic microorganisms isolates: Candida albicans ATCC 18804, C. glabrata ATCC 2001, C. parapsilosis ATCC 22019, C. krusei ATCC 2159, C. tropicalis ATCC 750, Bacillus cereus ATCC 11778, B. subtilis ATCC 6633, Enterococcus faecalis ATCC 4083, Escherichia coli ATCC 25922, Listeria monocytogenes ATCC 15313, Pseudomonas aeruginosa ATCC 25619, Salmonella typhimurium ATCC 13311, Staphylococcus aureus ATCC 12600, S. epidermidis ATCC 12118, S. saprophyticus ATCC 15305, Streptococcus pyogenes ATCC 8668, and S. pneumoniae ATCC 6314. The yeasts were maintained on GYMP agar slant medium, containing $2 \%$ glucose, 0.5 yeast extract, $1 \%$ malt extract, $0.2 \% \mathrm{Na}_{2} \mathrm{PO}_{4}$, and $2 \%$ agar ( $\mathrm{wt} / \mathrm{vol}$ ) with a mineral oil layer and kept at $4^{\circ} \mathrm{C}$ and subcultured every six months. Bacteria were maintained on brain heart infusion broth (BHI, Difco, US) with a mineral oil layer, kept at $-40^{\circ} \mathrm{C}$.

Inocula of the target microorganisms were adjusted to Mac Farland nr 1 scale in optical density for yeasts (Yarrow 1998) and $10^{3}-10^{4}$ cells $/ \mathrm{ml}$ for bacteria. The yeasts were grown in Agar Sabouraud (Difco) at $37^{\circ} \mathrm{C}$ for $24 \mathrm{~h}$ and inoculated using a swab onto a plate containing YM medium (malt extract $0.3 \%$, yeast extract $0.3 \%$, peptone $0.5 \%$, glucose $1 \%$, agar $2 \%$ ). The bacteria were grown in Agar Nutrient (peptone 1\%, $\mathrm{NaCl} 0.5 \%$, beef extract $0.3 \%$, agar $2 \%$ ), transferred to culture tubes with $6 \mathrm{ml} \mathrm{BHI} \mathrm{(Difco)}$ and incubated at $35^{\circ} \mathrm{C}$ for $24 \mathrm{~h}$. Before the assay, they were plated using a swab in BHI Agar (Difco).

The extract solutions at $1 \mathrm{mg} / \mathrm{ml}$ in aqueous $5 \%$ DMSO were applied $(10 \mu \mathrm{l})$ on the Petri dishes $(90 \times 15 \mathrm{~mm})$ with the target organisms and incubated for $24-48 \mathrm{~h}$ at $37^{\circ} \mathrm{C}$. Inhibition zones around the application points were then measured. Fluconazole $(12 \mathrm{mg} / \mathrm{ml})$ and chloramphenicol $(0.2 \mathrm{mg} / \mathrm{ml})$ were used as positive controls for yeasts and bacteria, respectively. Solvent (aqueous DMSO 5\%) was used as negative control.

\section{RESULTS AND DISCUSSION}

From the 103 extracts obtained, 15 (14\%) presented significant activity against one or more of the target microorganisms (Table II), generating inhibition halos larger than $12 \mathrm{~mm}$ diameter. Two extracts presented wide antimicrobial spectrum, and were active against both fungi and bacteria. Eight isolates were active against bacteria only while three inhibited the growth of fungi only.

The culture extract of Irpex lacteus was the most active, being able to inhibit the growth of C. albicans, C. glabrata, C. parapsilosis, B. cereus, E. coli, S. typhimurium, and $S$. aureus. Although this species is already known to produce a nematicidal compound (5-pentyl-2-furaldehyde) (Hayaschi et al. 1981), this is the first work reporting the antibiotic activity of this species. Another species $[I$. pachyodon (P.) Quél.] was reported to produce an active principle that inhibits the growth of E. coli, S. aureus and B. subtilis (Bianco et al. 1969).

Two Oudemansiella species, O. mucida and $O$. radicata, are known to produce several bioactive compounds denominated strobilurins and oudemansins. They are able to inhibit fungal growth at very low concentrations $\left(10^{-8}-10^{-7} \mathrm{M}\right)$ without any significant antibacterial activity (Anke et al. 1979, 1990, Anke 1990, Florianowicz 1999). These compounds kill opportunist pathogens such as C. albicans and dermatophytes belonging to the genus Trichophyton, Epidermophyton, and Microsporum (Anke 1997). In this work, the culture extract of $O$. canarii CCB179 presented a wide antifungal spectrum, inhibiting the growth of $C$. albicans, $C$. glabrata, C. krusei and C. tropicalis. Although this is the first report on the antifungal activity of this species it is reasonable to expect that the observed activity be due to the presence of one more compound already isolated from other Oudemansiella species.

Extracts from the basidiomes of Phellinus sp., Gloeoporus thelephoroides and Hexagonia hydnoides inhibited $B$. cereus growth while the extract from the culture of Nothopanus hygrophanus presented inhibitory activity against $L$. monocytogenes and $S$. aureus. This is the first report on the antibacterial activity of these species. Hwang et al. (2000) isolated the antifungal agent phellinsin A from Phellinus sp., capable of inhibiting the chitin synthase I and II of Saccharomyces cerevisiae with an $\mathrm{IC}_{50}$ value of $76 \mu \mathrm{g} / \mathrm{ml}$. Phellinsin A was able to inhibit the growth of fungi such as Colleotrichum lagenarium, Pyricularia oryzae, Rhizoctonia solani, Aspergillus fumigatus and Trichophyton mentagrophytes (Hwang et al. 2000). Several studies have showed that Phellinus species can produce substances with cytotoxic (Atsumi et al. 1990, 1993, Withers \& Umezawa 1991, Han et al. 1999), immunomodulatory (Song et al. 1995, Kim et al. 1996), antiviral (Walder et al. 1995), antioxidant, antihepatotoxic (Ajith \& Janardhnan 2002) activities.

The culture extract of Agrocybe perfecta was investigated for the first time and it displayed antifungal activity towards $C$. krusei. Species from this genus are known to produce bioactive compounds presenting antitumoral (Mavoungou et al. 1987), antifungal (Pujol et al. 1990), hypocholesterolemic, hypolipidemic (Wasser $\&$ Weis 1999) activity as well as antibacterial activity against $S$. aureus and E. coli (Hervey 1947). Agrocybin, a compound able to halt the growth of Gram-positive, Gramnegative and acid-fast bacteria, was isolated from Agrocybe dura (Kavanagh et al. 1950). Its activity against B. mycoides, B. subtilis, E. coli, Klebisiella pneumoniae, Mycobacterium pheli, M. smegmatis, Photobacterium fischeri, P. aeruginosa and $S$. aureus was demonstrated. Agrocybe cylindracea produces indole derivatives that act as radical scavengers and reduce lipid peroxidation of cells and organelles membranes (Kim et al. 1997). Thus, rat liver microsomes are protected by these compounds with $\mathrm{ED}_{50}$ values around $2 \mu \mathrm{g} / \mathrm{ml}$. Berg et al. (2002) report the isolation of agrocybolacton from Agrocybe sp. This compound shows moderate antibacterial activity against 


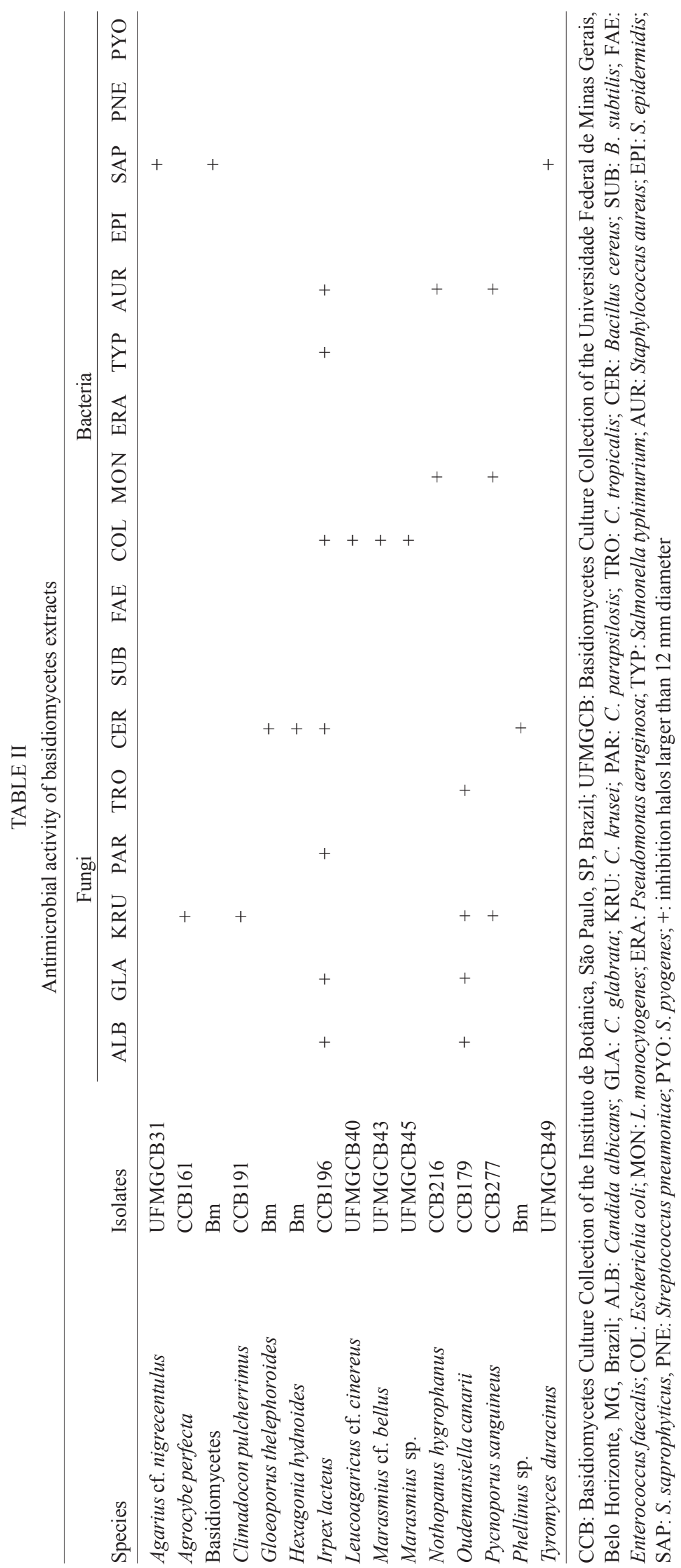


Gram-positive bacteria such as $B$. subtilis and $M$. smegmatis at concentrations near $50 \mu \mathrm{g} / \mathrm{ml}$.

The culture extracts from Marasmius cf. bellus and Marasmius sp. UFMGCB45 were capable of inhibiting the growth of E. coli. Within the family Tricholomataceae species of the genus Marasmius have long been known to produce interesting secondary metabolites (Anke et al. 1980). M. androsaceus produces a compound with antiinflammatory activity that is already commercialized (Wasser \& Weis 1999). Scorodonin, a biologically active metabolite from M. scorodonius, inhibits Gram-negative and Gram-positive bacteria as well as yeasts at rather high concentration (Anke et al. 1980). Two antimicrobial and cytotoxic metabolites denominated alliacols A and B were isolated from $M$. alliaceus. Although the alliacols show only weak antibacterial and antifungal activity, both antibiotics strongly inhibit DNA synthesis in cells of the ascitic form of Ehrlich carcinoma at concentration of 2-5 $\mu \mathrm{g} / \mathrm{ml}$ (Anke et al. 1981). Marasmic acid was shown to be an antibacterial, antifungal, cytotoxic, phytotoxic substance isolated from M. conigenus (Abraham 2001).

The culture extract from Agaricus cf. nigrecentulus showed antibacterial activity against $S$. saprophyticus. Several lectins were isolated from A. bisporus, A. blazei, A. campestris, and A. edulis (Vijayan \& Chandra 1999). Nearly sixty lectins with ability to retard cancer cell growth, without any apparent effect on normal cells, were isolated from $A$. bisporus and are commercially available (Wang et al. 1998). From the poisonous fungi A. xanthodermus several substances with antimicrobial, cytotoxic and antineoplastic activity were isolated (Dornberger et al. 1986). Culture extracts from Leucoagaricus $\mathrm{cf}$. cinereus inhibited E. coli. Basidalin, isolated from L. naucinus showed weak antibacterial activity against Aeromonas salmonicida (MIC $100 \mu \mathrm{g} / \mathrm{ml}$ ), Vibrio anguillarum (MIC $100 \mu \mathrm{g} / \mathrm{ml}$ ), and inhibited the synthesis of protein, RNA and DNA in cultured L1210 cells, the $\mathrm{IC}_{50}$ were $0.4-0.6 \mu \mathrm{g} / \mathrm{ml}$ (Iinuma et al. 1983). To the best of our knowledge, the species Climacodon pulcherrimus and Tyromyces duracinus are cited here for the first time as producers of antimicrobial compounds.

The antimicrobial activity of Pycnoporus sanguineus has been known since 1946, when Bose (1946) isolated poliporin, a compound active against Gram-positive and Gram-negative bacteria and without toxicity to experimental animals. More recently, studies by Smânia et al. (1995a, 1997) showed that this basidiomycete produces cinnabarine, an orange pigment active against B. cereus, E. faecalis, E. faecium, E. coli, K. pneumoniae, L. mesenteroides, L. plantarum, P. aeruginosa, Salmonella sp., S. typhi, S. aureus and several Streptococcus spp. Cinnabarine was more active against Gram-positive than against Gram-negative bacteria. According to Fidalgo (1965) some Brazilian indigenous people use the basidiomes of $P$. sanguineus to stop haemorrhages. Our results showed that from the six isolates tested, only CCB277 inhibited C. krusei, L. monocytogenes and $S$. aureus. We also observed discrepancies between the biological activities of two different $O$. canarii isolates. This is not uncommon, as infra-specific genetic differences have already been observed (Suay et al. 2000). Indeed, distinct secondary metabolites can be produced by cospecific isolates in other fungi, as already reported in the literature (Möller et al. 1996, Peláez et al. 1998, Okino et al. 2001). Thus, if secondary metabolic diversity is of interest, it is important to keep different samples/isolates of the same species of basidiomycetes in the collections.

Studies aiming at the isolation and identification of the active compounds from the most promising extracts disclosed in this research are currently under way. To the best of our knowledge, this survey is the first to investigate the potential of Brazilian basidiomycetes isolates on a larger scale, and can serve to stimulate the investigation of this rich source of bioactive secondary metabolites.

\section{ACKNOWLEDGMENTS}

To the Materials Reference Laboratory (Fiocruz-RJ) for the ATCC microorganisms.

\section{REFERENCES}

Abraham WR 2001. Bioactive sesquiterpenes produced by fungi: are they useful for humans as well? Curr Med Chem 8: 583-606.

Ajith TA, Janardhanan KK 2002. Antioxidante and antihepatotoxic activities of Phellinus rimosus (Berk) Pilat. $J$ Ethnopharmacol 81: 387-391.

Anke T 1989. Basidiomycetes: a source for new bioactive secondary metabolites. Prog Ind Microbiol 27: 51-66.

Anke T 1995. The antifungal strobilurins and their possible ecological role. Can J Bot 73: 940-945.

Anke T 1997. Strobilurins. In T Anke, Fungal Biotechnology, Chapman \& Hall, London, p. 206-212.

Anke T, Hecht HT, Schramm G, Streglich W 1979. Antibiotics from basidiomycetes. IX. Oudemansin, an antifungal antibiotic from Oudemansiella mucida (Schrader ex Fr.) Hoehnel (Agaricales). J Antibiot 32: 1112-1117.

Anke T, Kupka J, Schramm G, Steglich W 1980. Antibiotics from basidiomycetes. X. Scorodonin, a new antibacterial and antifungal metabolite from Marasmius scorononius (Fr.) Fr. J Antibiot 33: 463-467.

Anke T, Watson WH, Giannetti BM, Steglich W 1981. Antibiotics from basidiomycetes. XII. The alliacols A and B from Marasmius alliaceus. J Antibiot 34: 1271-1277.

Anke T, Werle A, Bross M, Steglich W 1990. Antibiotics from basidiomycetes. XXXIII. Oudemansin X, a new antifungal (E)- $\beta$-methoxyacrylate from Oudemansiella radicata (Relhan ex Fr.) Sing. J Antibiot 43: 1010-1011.

Atsumi S, Nosaka C, Ochi Y, Inhuma H, Umezawa K 1993. Inhibition of experimental metastasis by an apha-glucosidase inhibitor, 1,6-epi-cyclophellitol. Cancer Res 15: 48964899.

Atsumi S, Umezawa K, Iiuma H, Naganawa H, Nakamura H, Iitaks Y, Takeuchi T 1990. Production, isolation and structure determination of a novel beta-glucosidase inhibitor, cyclophellitol, from Phellinus sp. J Antibiot 43: 49-53.

Berg A, Dörfelt H, Kiet TT, Schelgel B, Gräfe U 2002. Agrocybolacton, a new bioactive metabolite from Agrocybe sp. HKI 0259. J Antibiot 55: 818-820.

Bianco MA, Scurti JC, Marchisio VF 1969. Su alcuni basdioimiceti lignicoli e di lettiera in relazione all'antibiosi. II. Attività antibatterica dei miceli e dei liquidi coltura. Allionia 15: 75-83.

Bose SR 1946. Antibiotics in a Polyporus (Polystictus sanguineus). Nature 158: 292-296.

Brizuela MA, Garcíam L, Pérez L, Mansur M 1998. Basidiomicetos: nueva fuente de metabolites secundários. Rev 
Iberoam Micol 15: 69-74.

Castellani A 1967. Maintenance and cultivation of common pathogenic fungi in distilled water. Further Researches. $J$ Trop Med Hyg 42:181-184.

Dennis RWG 1970. Fungus flora of Venezuela and adjacent countries. Kew Bull Add 3: 1-485.

Dornberger K, Ihn W, Schade W, Tresselt D, Zureck A, Radics L 1986. Evidence for the occurrence of the 4-hydroxybenzenediazonium ion in the extracts of Agaricus xanthodermus Genevier (Agaricales). Tetrahedron Lett 27: 559-560.

Fidalgo O 1965. Conhecimento micológico dos índios brasileiros. Rickia 2: 1-10.

Florianowicz T 1999. Antifungal activity of some metabolites of higher fungi (Basidiomycetes) - An overview. Acta Soc Bot Poloniae 68: 307-310.

Gilbertson RL, Ryvarden L 1986. North American Polypores, Fungiflora, Oslo, 433 pp.

Gilbertson RL, Ryvarden L 1987. North American Polypores, Fungiflora, Oslo, $451 \mathrm{pp}$.

Han SB, Lee CW, Jeon YJ, Hong ND, Yoo ID, Yang KH, Kim HM 1999. The inhibitory effect of polysaccharide isolated from Phellinus linteus on tumor growth and metastasis. Immunopharmacology 4: 157-164.

Hayaschi M,Wada K, Munakata K 1981. New nematicidal metabolites from a fungus, Irpex lacteus. Agric Biol Chem 45: 1527-1529.

Hawksworth DL 1991. The fungal dimension of biodiversity: magnitude, significance, and conservation. Mycol Res 95: 641-655.

Heinemann P 1961. Agaricus of Trinidad. Kew Bull 15: 231 248.

Heinemann P 1977. Flore illustrée des champignons d'Afrique centrale-Leucocoprinus (Agaricaceae). Bull Jard Bot Nat Belg 5: 87-109.

Heinemann P 1993. Agariceae des régions intertropicales d'Amerique du Sul. Bull Jard Bot Nat Belg 62: 355-384.

Hervey AH 1947. A survey of 500 basidiomycetes for antibacterial activity. Bull Torrey Bot Club 74: 476-503.

Hwang EI, Yun BS, Kim YK, Kwon BM, Kim HG, Lee HB, Jeong W, Kim SU 2000. Phellinsin A, a novel chitin synthase inhibitor produced by Phellinus sp. PL3. J Antibiot 53: 903911.

Iinuma $H$, Nakamura $H$, Naganawa $H$, Masuda $T$, Takano $S$, Takeuchi T, Umezawa H, Iitaka Y, Obayashi A 1983. Basidalin, a new antibiotic from basidiomycetes. $J$ Antibiot 36: $448-450$

Ishikawa NK, Kasuya MCM, Vanetti MD 2001. Antibacterial activity of Lentinula edodes grown in liquid medium. Braz JMicrobiol 32: 205-210.

Kavanagh F, Hervey A, Robbins WJ 1950. Antibiotic substances from basidiomycetes. VI. Agrocybe dura. Proc Natl Acad Sci USA 36: 102-106.

Kim HM, Han SB, Oh GT, Kim YH, Hong KH, Hong ND, Yoo ID 1996. Stimulation of humoral and cell mediated immunity by polysaccharide from mushroom Phellinus linteus. Int J Immunopharmac 18: 295-303.

Kim WG, Lee IK, Kim JP, Ryoo IJ, Koshino H, Yoo ID 1997. New indole derivatives with free radical scavenging activity from Agrocybe cylindracea. J Nat Prod 60: 721-723.

Kotra LP, Mobashery S 1998. $\beta$-lactam antibiotics, $\beta$-lactamases and bacterial resistance. Bull Inst Pasteur 96: 139-150.

Mavoungou H, Porte M, Oddoux L 1987. Activité antitumorale des mycéliums d'Agrocybe dura, Mycoacia uda et Phanerochaete laevis. Ann Pharmaceutiques Françaises 45: 71-77.
Maziero R, Cavazzoni V, Bononi VLR 1999. Screening of basidiomycetes for the production of exopolysaccharide and biomass in submerged culture. Rev Microbiol 30 : 77-84.

Möller C, Weber G, Dreyfuss MM 1996. Intraspecific diversity in the fungal species Chaunopycnis alba: implications for microbial screening programs. J Ind Microbiol 17: 359-372.

Morschhäuser J, Köhler G, Ziebuhr W, Blum-Oehler G, Dobrindt U, Hacker J 2000. Evolution of microbial pathogens. Phil Trans R Soc Lond B 355: 695-704.

Okino LK, Machado KMG, Fabris C, Bononi VLR 2001. Ligninolytic activity of tropical rainforest basidiomycetes. World J Microbiol Biotechnol 16: 889-893.

Oliveira JM, Jordão BQ, Ribeiro LR, Eira AF, Mantovani MS 2002. Anti-genotoxic effect of aqueous extracts of sun mushroom (Agaricus blazei Murill lineage 99/26) in mammalian cells in vitro. Food Chem Toxicol 40: 17751780 .

Paccola AS, Maki CS, Nobrega GMA, Paccola-Meirelles LD 2001. Antagonistic effect of edible mushrooms extract on Candida albicans growth. Braz J Microbiol 32: 176-178.

Pegler DN 1983. Agaric flora of the Lesser Antilles. Kew Bull Add 9: 1-669.

Pegler DN 1997. The Agarics of São Paulo, Brazil: an Account of the Agaricoid Fungi (Holobasidiomycetes) of São Paulo State, Brazil, Royal Botanic Gardens, United Kingdon, 68 pp.

Peláez F, Collado J, Arenal F, Basilio A, Cabello A, Díez Matas MT, Garcia JB, Val AGD, Gonzáles V, Gorrochategui J, Hernández P, Martín I, Platas G, Vicente F 1998. Endophytic fungi from plants living on gypsum soils as a source of secondary metabolites with antimicrobial activity. Mycol Res 102: 755-761.

Pujol V, Seux V, Villard J 1990. Recherche de substances antifongiques sécrétées par les champignons supérieurs en culture. Ann Pharmaceutiques Françaises 48: 17-22.

Ryvarden L 1987. New and noteworthy polypores from Tropical America. Mycotaxon 28: 525-541.

Ryvarden L 1991. Genera of Polypores. Nomenclature and Taxonomy, Fungiflora, Oslo, 363 pp.

Sandven P 2000. Epidemiology of canidemia. Rev Iberoam Micol 17: 73-81.

Sidorova II, Velikanov LL 2000. Bioactive substances of agaricoid basidiomycetes and their possible role in regulation of myco- and microbiota structure in soils of forest ecosystems. I. Antibiotic activity of water extracts from basidioms of several dominant agaricoid basidiomycetes. Mikol Fitopatol 34: 11-17.

Smânia A, Dellemonache F, Smânia EFA, Gil ML, Benchetrit LC, Cruz FS 1995a. Antibacterial activity of a substance produced by the fungus Pycnoporus sanguineus (Fr.) Murr. J Ethnopharmacol 45: 177-181.

Smânia A, Monache FD, Smânia EFA, Cuneo RS 1999. Antibacterial activity of steroidal compounds isolated from Ganoderma applanatum (Pers.) Pat. (Aphyllophoromycetideae) Fruit body. Int J Med Mushrooms 1: 325-330.

Smânia A, Smânia EFA, Cruz FS, Benchetrit LC 1995b. Growth and production phases of Pycnoporus sanguineus. Rev Microbiol 26: 302-306.

Smânia EFA, Smânia A, Loguercio-Leite C, Gil ML 1997. Optimal parameters for cinnabarin synthesis by Pycnoporus sanguineus. J Chem Technol Biotechnol 70: 57-59.

Song KS, Cho SM, Lee JH, Kim HM, Han SB, Ko KS, Yoo ID 1995. B-lymphocyte-stimulating polysaccharide from mushroom Phellinus linteus. Chem pharm Bull 43: 21052108. 
Suay I, Arenal F, Asensio FJ, Basilio A, Cabello MA, Díez MT, García JB, Val AG, Gorrochategui J, Hernández P, Peláez F, Vicente MF 2000. Screening of basidiomycetes for antimicrobial activities. Antonie Van Leeuwenhoek 78: 129139.

Thomson KS, Moland ES 2000. Version 2000: the new blactamases of Gram-negative bacteria at the dawn of the new millennium. Microbes and Infection 2: 1225-1235.

Vijayan M, Chandra N 1999. Lectins. Curr Op Struct Biol 9: 707-714.

Walder R, Kalvatchev Z, Garzaro D, Barrios M 1995. Natural products from the tropical rain forest of Venezuela inhibitors of HIV- replication. Acta Cient Venez 46: 110-114.
Wang H, Ng TB, Ooi VEC 1998. Lectins from mushrooms. Mycol Res 102: 897-906.

Wasser SP, Weis AL 1999. Therapeutic effects of substances occurring in higher basidiomycetes mushrooms: a modern perspective. Crit Rev Immunol 19: 65-96.

Withers SG, Umezawa K 1991. Cyclophellitol: a naturally occurring mechanism-based inactivator of betaglucosidases. Biochem Biophys Res Commun 31: 532537.

Yarrow D 1998. Methods for the isolation, maintenance and identification of yeasts. In CP Kurtzman, JW Fell (eds), The Yeasts: a Taxonomic Study, Elsevier, Amsterdam. p. $77-105$ 